Article

\title{
Digital Entrepreneurship: Public Perception of Barriers, Drivers, and Future
}

\author{
Isabelle Biclesanu $^{1}$, Sorin Anagnoste ${ }^{1, * \mathbb{D}}$, Ovidiu Branga ${ }^{1}$ and Marco Savastano $^{2}$ (D) \\ 1 Faculty of Business Administration in Foreign Languages, Bucharest University of Economic Studies, \\ 010731 Bucharest, Romania; isabelle.bn@pm.me (I.B.); ovidiubranga@yahoo.com (O.B.) \\ 2 Management Department, Sapienza University of Rome, 00161 Rome, Italy; marco.savastano@uniroma1.it \\ * Correspondence: sorin.anagnoste@fabiz.ase.ro
}

Citation: Biclesanu, Isabelle, Sorin Anagnoste, Ovidiu Branga, and Marco Savastano. 2021. Digital Entrepreneurship: Public Perception of Barriers, Drivers, and Future. Administrative Sciences 11: 125. https://doi.org/10.3390/ admsci11040125

Received: 6 September 2021

Accepted: 29 October 2021

Published: 3 November 2021

Publisher's Note: MDPI stays neutral with regard to jurisdictional claims in published maps and institutional affiliations.

Copyright: (C) 2021 by the authors Licensee MDPI, Basel, Switzerland. This article is an open access article distributed under the terms and conditions of the Creative Commons Attribution (CC BY) license (https:// creativecommons.org/licenses/by/ $4.0 /)$.

\begin{abstract}
The widespread access to the Internet has undoubtedly changed the way businesses handle their processes and interact with their customers. With the surge of new devices, business models, technologies, and platforms, alongside social media growth and innovative advertising, it became easier to transition from employment to entrepreneurship. The paper aims to assess the public perception of digital entrepreneurship, with a focus on its barriers, drivers, and expectations for the future. The results show that there is a slight agreement with a digital business being easier to establish compared with a traditional one. The driving forces behind starting a digital business are recognized, and the digital environment is considered essential for business growth in the following years. With some exceptions, there are no significant differences between age groups, genders, relationship statuses, levels of education, and/or occupations when rating the barriers, drivers, and expectations for the future of digital entrepreneurship.
\end{abstract}

Keywords: digital entrepreneurship; online business; e-business; e-commerce; technology entrepreneurship; online platform; social media; digital transformation

\section{Introduction}

The widespread access to the Internet has undoubtedly changed the way in which businesses handle their processes and interact with their customers.

While entrepreneurship has been around for thousands of years, the concept of digital entrepreneurship has only recently been introduced to the business landscape. However, what is currently being defined as digital entrepreneurship greatly differs from what it was at its beginning. In the early days of the Internet, digital entrepreneurship implied transforming an existing business venture to accommodate the online environment, usually by building a website (McCullough 2018). Nowadays, digital entrepreneurship has evolved into a much larger meaning due to the advancements in technology (Johnson 2021; Le Dinh et al. 2018). Digital entrepreneurship incorporates businesses whose main activities are made possible through the use of digital technologies (Allen 2019). Thus, digital entrepreneurship could be defined as the process of creating and pursuing entrepreneurship opportunities through the use of information and communication technology (ICT) (Antonizzi and Smuts 2020; Sussan and Acs 2017) and seen as "the reconciliation of traditional entrepreneurship with the new way of creating and doing business in the digital era" (Le Dinh et al. 2018, p. 1).

While established corporations mostly rely on incremental innovation of their business models, driving efficiency, and creating value for the ever-changing market expectations by implementing new technologies and ways of carrying out their activities (BCG 2021; Ang and Jamshed 2021; Anagnoste et al. 2021; Savastano and Anagnoste, 2020), start-ups have more flexibility to produce creative disruption, innovative business models, and value propositions. Regardless, looking at the two most common approaches of doing business, namely business-to-consumer (B2C) and business-to-business (B2B), B2C seems to be more 
adaptable to new technologies. For example, smartphones generate the most $\mathrm{B} 2 \mathrm{C}$ traffic (Cassidy 2019). However, while mobile drives traffic, ultimately, the sales mostly come from a computer (BroadbandSearch 2021). This might happen because customers are still uncomfortable finalizing purchases on mobile devices (Bhatia 2020). In contrast, the B2B model ranks lower in terms of its adaptation to digital entrepreneurship, as transactions usually require direct contact and negotiation as opposed to having an online shopping cart experience (Balance 2021). For example, in the United States of America, the B2B market generated $\$ 9$ trillion sales in 2018, out of which only $12 \%$ were made online. This percentage is expected to reach $17 \%$ by 2023 (Bruno 2019). However, global B2B e-commerce accounted for $82 \%$ of all e-commerce in 2019 , based on market value (UNCTAD 2021).

Digital tools enable collaboration and knowledge sharing within new social dynamics (Sahut et al. 2021), and with the surge of new devices, business models, technologies, and platforms, alongside social media growth and innovative advertising, it became easier to transition from employment to entrepreneurship.

\section{Context}

Although the ideas of personal computers and the Internet were very much exploratory and adventurous in the 80 s, the 90 s propelled digital entrepreneurship through the dot-com bubble (Smith 2011). With digitalization came new ways for businesses to manage their processes, interact with their customers, and market their offerings (Schallmo and Williams 2018).

In 1994, the first Internet browser was introduced, Netscape Navigator (Sharwood 2014). Amazon appeared a year later as an e-commerce platform for books and grew over the next three decades to be one of the biggest companies in the world (Miva 2011; Fortune 2021). Successful e-commerce companies perfected the customer's purchase journey by understanding the drivers of customer satisfaction and optimizing customer experience (Anagnoste et al. 2020; Teneva 2021).

Following all the hype and speculation placed around the Internet during its beginning, the 2000s brought digital entrepreneurship to the hands of the masses (CSP 2016). With desktop computers becoming more affordable (Statista 2021a) and a home Internet connection increasingly more common (Ariguzo et al. 2006), it did not take long for people and companies to start interacting in new ways.

Social media platforms began taking shape, and by the mid-2000s, companies such as Facebook and Myspace were exploding in popularity (Edosomwan et al. 2011). Nowadays, there is a plethora of social media platforms specialized in short videos, visuals, short conversations, the professional environment, and so on. The growth of the social media industry and its marketing capabilities turned out to be of great support for digital entrepreneurship by creating new opportunities for people to start a business that takes advantage of the digital environment.

This expansion of the social media industry led to innovative marketing approaches. Currently, traditional advertising is becoming increasingly unattractive, with digital advertising spending expected to overpass traditional ad spending in the next five years (Buchholz 2020) and start generating more revenue from mobile devices compared with desktops (Statista 2021b).

The technological developments alleviate part of the challenges faced by entrepreneurs, especially since the costs involved in using or implementing some technologies are lowering (Rayna and Striukova 2021; Koetsier 2021). However, digital entrepreneurship in developing countries is affected by the weak infrastructures supporting the access to start-up funds, the lack of protective and stimulating policies, the weak digital infrastructure, and deficiencies in digitally competent human resources (Samara and Terzian 2020). Moreover, new technology adoption within companies comes with change management challenges. For instance, some studies show the disruptive effect of big data and blockchain over job profiles and organizational structure (Tiron-Tudor and Deliu 2021; Tiron-Tudor et al. 2021).

As a result of the dynamic growth of technology, how fast entrepreneurs and consumers are accepting and integrating it became a complex problem. A number of re- 
searchers have developed technology adoption theories and frameworks with the aim of understanding consumer behavior (Venkatesh and Davis 1996; Venkatesh et al. 2003; Dapp et al. 2012; Lai and Zainal 2015). For example, the Technology Acceptance Model (TAM) was first proposed in 1986 to explain computer usage behavior, and since then, it has gone through multiple iterations, including different predictor variables (Lai 2017). With the aim of nurturing entrepreneurial behavior, Elia et al. (2021) proposed a model for a Digital Society incubator, which combines the digital and entrepreneurial environments, taking into account the required actors, flows, processes, and values. Moreover, Satalkina and Steiner (2020a) divided the determinants of digital entrepreneurship within three innovation system dimensions: the ecosystem, the entrepreneur, and the entrepreneurial process.

Fundamentally, the ease of having a digital business has a positive relationship with the level of digital evolution within a country, digital entrepreneurship being a contributor to the innovation system (Satalkina and Steiner 2020b).

Contrary to the general fear that the COVID-19 pandemic would generate a decrease in spending (Anderson 2021), it increased sales, especially in e-commerce (UNCTAD 2021; Statista 2021c). The interest for "digital" has grown starting March 2020, as presented in Figure 1, for all the categories of search worldwide. The "digital" keyword registered a significantly higher search volume in March 2020-August 2021 compared with the August 2016-March 2020 period, $\mathrm{t}(258)=-33.2, p<0.001$.

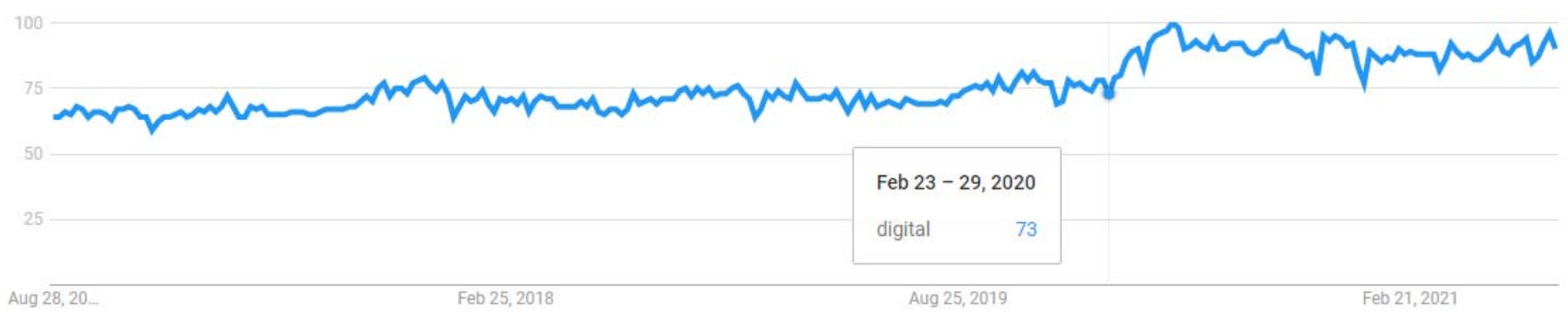

Figure 1. Google trends worldwide interest for the "digital" keyword in the August 2016-August 2021 period for all categories of search. Source: Google trends.

Similarly, the interest in "e-commerce" has grown starting March 2020, as available in Figure 2. The "e-commerce" keyword registered a significantly higher search volume in March 2020-August 2021 compared with the August 2016-March 2020 period, $\mathrm{t}(258)=-17.3, p<0.001$.

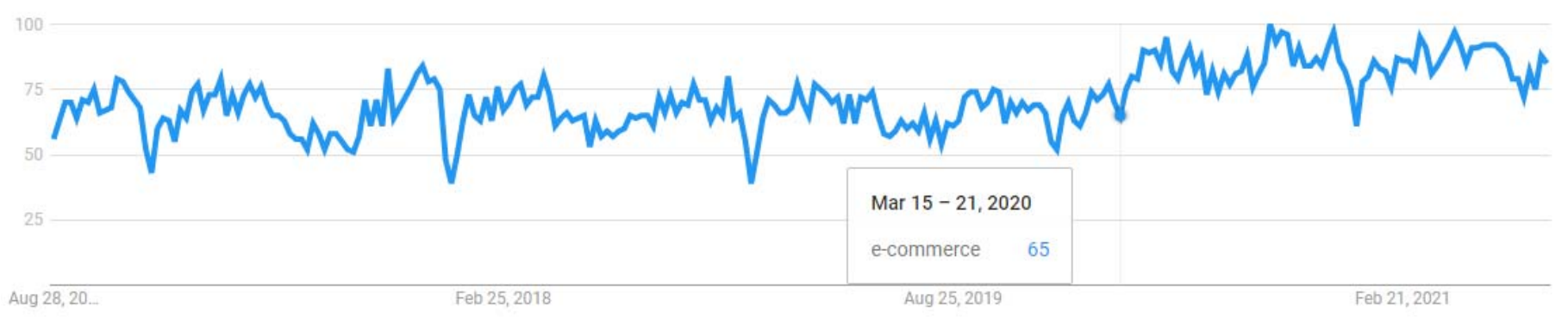

Figure 2. Google trends worldwide interest for the "e-commerce" keyword in the August 2016-August 2021 period for all categories of search. Source: Google trends.

The COVID-19 crisis is likely to produce an increase in nationalist policies in corporate law, with long-term orientation toward stakeholder interests (Gelter and Puaschunder 2021). Wise capital allocation seems to be of foremost importance (Patel and Patel 2020), while family shareholders having controlling positions within the organization is one of the determinants of organizational resilience (Amore et al. 2020).

However, with the difficulties in running a traditional business came a sudden interest for anything online, including start-ups (Tai 2021). 


\section{Research Aims}

As the digital environment's attractiveness has increased because of the pandemic, this paper aims to assess the current public perception of digital entrepreneurship, with a focus on its barriers, drivers, and expectations for the future. There is no national digital transformation strategy for enterprises in Romania (European Commission 2020) and understanding the present view over digital entrepreneurship is valuable for developing support measures for the digitalization of companies as well as awareness programs to address digital technologies' benefits.

The investigation will be based on the following questions $\left(\mathrm{Q}_{1}-\mathrm{Q}_{4}\right)$ and hypotheses $\left(\mathrm{H}_{1}-\mathrm{H}_{2}\right)$ :

$\mathrm{Q}_{1}$ : "Is a digital business considered to be easier to establish compared with a traditional one?"

The challenge level refers to the starting investment; the required level of research, knowledge, time, and the number of employees needed for starting a digital business compared with a traditional one; as well as the legal standpoint and the perceived level of risk.

$\mathrm{Q}_{2}$ : "Are the driving forces behind starting a digital business recognized?"

The question investigates public perception of drivers, such as social media, the influence of self-proclaimed digital business experts, the digital age generations reaching adulthood and the right to own a business, the work-life balance, and the possibility of achieving a high level of income through a digital business.

$\mathrm{Q}_{3}$ : "Is the digital environment considered essential for business growth in the following years?"

$\mathrm{Q}_{4}$ : "Are there significant differences in rating the barriers, drivers, and expectations for the future of digital entrepreneurship, between age groups, genders, relationship statuses, levels of education, and/or occupations?"

Hypothesis $\mathbf{1}\left(\mathbf{H}_{\mathbf{1}}\right)$. A lower level of perceived barriers in starting a digital business coincides with a higher level of trust that the digital environment is essential for business growth in the following years.

Hypothesis $2 \mathbf{( H}_{\mathbf{2}} \mathbf{)}$. A higher level of perceived strength of the driving forces behind starting a digital business coincides with a higher level of trust that the digital environment is essential for business growth in the following years.

\section{Research Methods}

A self-administered, online survey collected 221 valid answers from Romanian citizens during May 2021. Data were collected through random and snowball sampling. The sample size meets the requirements for a 95\% confidence level with 6.6\% margin of error.

The first section of the survey is aimed at gathering demographic data (i.e., gender, age, relationship status, occupation, and the highest level of education completed). The second and last section has 27 Likert-style items for assessing the respondents' opinion on digital entrepreneurship, rated on a scale from 1 to 7 ( 1 = "strongly disagree"; 7 = "strongly agree").

Data analysis was performed in SPSS. A principal components analysis (PCA) was used for the Likert items and checked against a parallel analysis. The internal consistency was measured through Cronbach's alpha, with values over 0.7 being considered reliable. Index variables were constructed for each of the latent variables through arithmetic mean of their items. Cluster analysis was performed based on the demographic variables. Tests of association, correlation, and difference of means were used where appropriate. 


\section{Findings}

\subsection{Factor Analysis}

Three Likert items were removed as a result of PCA. After comparing the scree plot and eigenvalues with a parallel analysis, the remaining 24 items were split into three factors: (1) barriers, representing the respondents' belief that a digital business would be easier to establish compared with a traditional one; (2) drivers, representing the recognition of the digital business driving forces; and (3) future, representing the respondents' belief that the digital environment is essential for business growth in the following years. The items constructing the barriers factor were coded b1-b8, the ones for drivers $\mathrm{d} 1-\mathrm{d} 10$, and the ones for future f1-f6. Each factor is presented in Table 1.

Table 1. Factor analysis results.

\begin{tabular}{|c|c|c|c|}
\hline Factor & Item Code & Item & Cronbach's Alpha (std.) \\
\hline \multirow{8}{*}{ barriers } & b1 & $\begin{array}{l}\text { The starting investment needed for a digital business is lower than the } \\
\text { one for a traditional business. }\end{array}$ & \multirow{8}{*}{0.747} \\
\hline & b2 & $\begin{array}{l}\text { The required level of research needed for starting a digital business is } \\
\text { lower than the one for a traditional business. }\end{array}$ & \\
\hline & b3 & $\begin{array}{l}\text { From a legal standpoint, it is easier to start a digital business than a } \\
\text { traditional one. }\end{array}$ & \\
\hline & $\mathrm{b} 4$ & Starting a traditional business is risky. & \\
\hline & b5 & The starting investment for a traditional business is high. & \\
\hline & b6 & Running a traditional business requires a substantial time investment. & \\
\hline & b7 & Starting a traditional business requires a high level of knowledge. & \\
\hline & b8 & Traditional businesses need more employees than digital businesses. & \\
\hline \multirow{10}{*}{ drivers } & $\mathrm{d} 1$ & $\begin{array}{l}\text { Social media content plays an important part in promoting the idea of } \\
\text { starting a digital business. }\end{array}$ & \multirow{10}{*}{0.873} \\
\hline & $\mathrm{d} 2$ & $\begin{array}{l}\text { A better work-life balance is an important motivating factor in starting a } \\
\text { digital business. }\end{array}$ & \\
\hline & $\mathrm{d} 3$ & $\begin{array}{l}\text { The possibility of achieving a high level of income is an important } \\
\text { motivating factor in starting a digital business. }\end{array}$ & \\
\hline & $\mathrm{d} 4$ & $\begin{array}{l}\text { The social status associated to entrepreneurs is an important } \\
\text { motivating factor. }\end{array}$ & \\
\hline & d5 & $\begin{array}{l}\text { Work satisfaction is higher when owning a business as opposed to being } \\
\text { an employee. }\end{array}$ & \\
\hline & d6 & $\begin{array}{l}\text { There is a strong link between social media and the recent interest for } \\
\text { digital businesses. }\end{array}$ & \\
\hline & $\mathrm{d} 7$ & $\begin{array}{l}\text { The self-proclaimed digital business experts generate much of the } \\
\text { interest for starting an online business. }\end{array}$ & \\
\hline & $\mathrm{d} 8$ & Social media advertising has amplified the interest for digital businesses. & \\
\hline & d9 & $\begin{array}{l}\text { Social media introduces the business environment to people of } \\
\text { increasingly younger ages. }\end{array}$ & \\
\hline & $\mathrm{d} 10$ & $\begin{array}{l}\text { The desire to own a business is greater for people born in the digital age } \\
\text { (after 1990). }\end{array}$ & \\
\hline \multirow{3}{*}{ future } & f1 & $\begin{array}{l}\text { In the near future, the turnover of the digital business market will } \\
\text { surpass the one for the traditional business market. }\end{array}$ & \multirow{3}{*}{0.798} \\
\hline & $\mathrm{f} 2$ & $\begin{array}{l}\text { It is essential for a business to have a social media presence in order to } \\
\text { stay relevant. }\end{array}$ & \\
\hline & $\mathrm{f} 3$ & It is important for a business to use targeted social media advertising. & \\
\hline
\end{tabular}


Table 1. Cont.

\begin{tabular}{|c|c|c|c|}
\hline Factor & Item Code & Item & Cronbach's Alpha (std.) \\
\hline & $\mathrm{f} 4$ & $\begin{array}{l}\text { Digital businesses will replace many traditional businesses in the } \\
\text { following } 10 \text { years. }\end{array}$ & \\
\hline & f5 & $\begin{array}{l}\text { Companies that will not adapt to the digital environment will fail to } \\
\text { be competitive. }\end{array}$ & \\
\hline & f6 & $\begin{array}{l}\text { People will prefer to shop online for increasingly more products } \\
\text { and services. }\end{array}$ & \\
\hline
\end{tabular}

Source: Analysis of the dataset in SPSS.

The factors have acceptable reliability values, $\mathrm{KMO}=0.884>0.6$, and Bartlett's test of sphericity $p<0.001$. The three factors explain $46.53 \%$ of the variance.

The lowest item mean was observed for $\mathrm{b} 2(\mathrm{M}=3.76, \mathrm{SD}=1.726$, Skewness $=0.156$, Kurtosis $=-0.791$, which is significantly lower than the scale midpoint of $4, \mathrm{t}(220)=-2.062$, $p<0.05$, showing that the respondents might believe the level of research needed for starting a digital business not to be lower than the one needed for starting a traditional business.

All the other items had means statistically higher than the Likert scale midpoint, showing a level of agreement with the statements, $p<0.05$.

Index variables were constructed for each of the latent variables through arithmetic mean of their items and will be referred to as: BARRIERS (the respondents' belief that a digital business would be easier to establish compared with a traditional one), DRIVERS (the recognition of the digital business driving forces), and FUTURE (the respondents' belief that the digital environment is essential for business growth in the following years).

As presented in Table 2, BARRIERS, DRIVERS, and FUTURE have moderate tendencies to vary in the same direction, validating $\mathrm{H}_{1}$ and $\mathrm{H}_{2}$.

Table 2. Intercorrelations and descriptive statistics of the index variables.

\begin{tabular}{lrrr}
\hline & BARRIERS & DRIVERS & FUTURE \\
\hline BARRIERS & 1 & & \\
DRIVERS & $0.449^{* *}$ & 1 & \\
FUTURE & $0.432^{* *}$ & $0.628^{* *}$ & 1 \\
$\quad$ Mean & 4.9 & 5.79 & 5.75 \\
$\quad$ Std. Deviation & 0.91 & 0.86 & 0.97 \\
${ }^{* *} p<0.001$. Source: SPSS. & &
\end{tabular}

The respondents believe that a digital business would be easier to establish compared with a traditional one, the BARRIERS variable $(\mathrm{M}=4.9, \mathrm{SD}=0.91)$ having a significantly higher mean compared with the scale mean of $4, t(220)=14.89, p<0.001$, thus answering $Q_{1}$. However, with a mean of 4.9 , the answers fall into the "slight agreement" range.

The driving forces behind starting a digital business are recognized, with DRIVERS $(\mathrm{M}=5.79, \mathrm{SD}=0.86)$ having a significantly higher mean compared with the scale mean of $4, \mathrm{t}(220)=30.83, p<0.001$, answering $\mathrm{Q}_{2}$.

The respondents consider that the digital environment is essential for business growth in the following years, the FUTURE variable $(\mathrm{M}=5.75, \mathrm{SD}=0.97)$ having a significantly higher mean compared with the scale mean of $4, t(220)=26.89, p<0.001$, thus answering $\mathrm{Q}_{3}$.

\subsection{Demographic Differences in Rating the Statements}

This section aims to answer $\mathrm{Q}_{4}$.

The 221 valid answers came mostly from the younger generations, as available in Table 3. 
Table 3. Dataset demographics.

\begin{tabular}{|c|c|c|c|}
\hline Item & Value & Frequency & Percent \\
\hline \multirow{5}{*}{ age } & $18-24$ & 164 & 74.2 \\
\hline & $25-34$ & 46 & 20.8 \\
\hline & $35-44$ & 8 & 3.6 \\
\hline & $45-54$ & 2 & 0.9 \\
\hline & $55-64$ & 1 & 0.5 \\
\hline \multirow{2}{*}{ gender } & man & 46 & 20.8 \\
\hline & woman & 175 & 79.2 \\
\hline \multirow{4}{*}{ relationship status } & single & 92 & 41.6 \\
\hline & in a relationship & 94 & 42.5 \\
\hline & engaged & 9 & 4.1 \\
\hline & married & 26 & 11.8 \\
\hline \multirow{4}{*}{$\begin{array}{l}\text { highest education } \\
\text { level completed }\end{array}$} & high school & 125 & 56.6 \\
\hline & bachelor's degree & 63 & 28.5 \\
\hline & master's degree & 31 & 14 \\
\hline & $\mathrm{PhD}$ & 2 & 0.9 \\
\hline \multirow{4}{*}{ occupation } & unemployed & 43 & 19.5 \\
\hline & employed & 121 & 54.8 \\
\hline & self-employed & 47 & 21.3 \\
\hline & entrepreneur & 10 & 4.4 \\
\hline
\end{tabular}

Source: Analysis of the dataset in SPSS.

All demographic variables have very weak associations with the three index variables, Eta coefficients $<0.19$.

Regarding their level of agreement with the statements, entrepreneurs were the only sub-group who did not have a statistically significant difference between the mean of each of the index variables and the scale mean of 4 . In their case, the BARRIER variable mean was not statistically different than the neutral point, $t(9)=1.906, p=0.09$, showing that entrepreneurs might not consider the barriers for digital businesses as being lower compared with the ones for traditional businesses. However, this result is influenced by the modest number of entrepreneurs in the sample.

The dataset was split into two clusters based on the age, relationship status, and education level items, as resulting from the Ward method in hierarchical cluster analysis, followed by the $k$-means cluster analysis. Gender and occupation were not deemed significant for clustering. A visual representation of the clusters is available in Figure 3.

Cluster 1 has 30 cases and is comprised of the respondents who are mostly in the upper levels based on age, relationship status, and education. Cluster 1 has no unemployed or single respondents. Cluster 2 has 191 cases and is represented by the people who are mostly in the lower levels based on age, education, and relationship status. Cluster 2 has no respondents over 45 years old or married. Cluster 1 has a lower number of cases compared with cluster 2; however, the differences between clusters are significant, $p<0.001$, showing cluster 1 as acceptable but underrepresented as a result of the demographic distribution of the sample.

There were no statistically significant differences between the ways the two clusters rated each of the index variables, $p>0.05$. However, women in cluster 1 (representing $66 \%$ of the cluster) had a weak to moderate tendency to rate the DRIVER and FUTURE variables higher, Eta $=0.430$ and Eta $=0.307$, respectively, compared with men in the same 
cluster, the difference being significant $p<0.05$ for the DRIVERS variable. Still, this result is influenced by the small number of cases in cluster 1 .

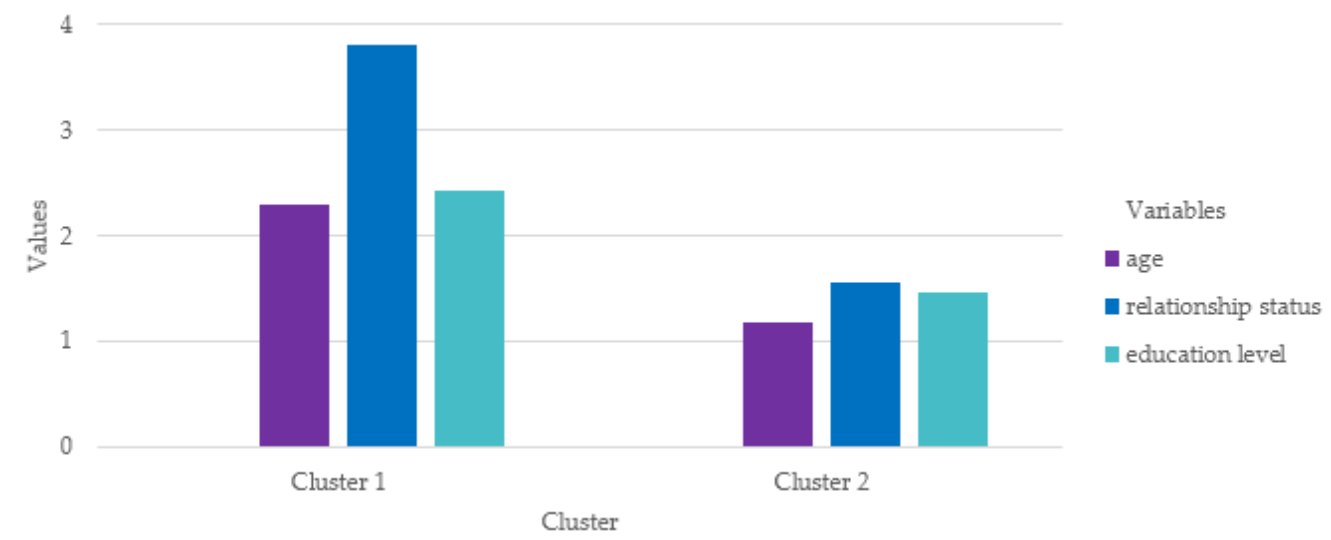

Figure 3. Dataset clustering based on age, relationship status, and education level, as represented by the cluster center values. Source: Authors' elaboration in SPSS.

\section{Discussion}

There is a slight agreement with a digital business being easier to establish compared with a traditional one when considering the starting investment need, the level of research, knowledge, time, and the number of employees required for starting the business as well as the legal standpoint and the perceived level of risk. Moreover, the driving forces behind starting a digital business are recognized, such as the influence of social media and selfproclaimed digital business experts, the digital age generations reaching adulthood and the right to own a business, or the hopes of having a better work-life balance and the possibility of achieving a high level of income through a digital business.

The respondents' belief that a digital business would be easier to establish compared with a traditional one and the recognition of the digital business driving forces have moderate tendencies to vary in the same direction with the respondents' belief that the digital environment will be essential for business growth in the following years.

In terms of socio-demographics, there are no significant differences in rating the barriers, drivers, and expectations for the future of digital entrepreneurship between age groups, genders, relationship statuses, levels of education, and/or occupations. However, entrepreneurs might not consider the barriers for digital businesses as being lower compared with the ones for traditional businesses.

There were no statistically significant differences between the ways people who are mostly in the upper levels based on age, relationship status, and education (cluster 1) rated their agreement level with the statements concerning the barriers, drivers, and expectations for the future of digital business compared with people on the lower levels of these demographic variables (cluster 2). As an exception, women in cluster 1 had a weak-moderate tendency to rate the DRIVER variable higher, $p<0.05$, compared with men in the same cluster.

The national innovation systems approach underlines the importance of the flows of technology and information between institutions, enterprises, and people to the innovative process (OECD 1997). With the difficulties in running a traditional business that have resulted from the COVID-19 pandemic (Tai 2021), and since the ease of having a digital business has a positive relationship with the level of digital evolution within a country (Satalkina and Steiner 2020b), a positive outlook on the national innovation systems could be considered as a result of the potential growth in digital entrepreneurship in the following years. Moreover, since Romania lacks a national digital transformation strategy for enterprises (European Commission 2020), by analysing the public perception of digital entrepreneurship, this paper contributes to the development of support mea- 
sures for the digitalization of companies as well as awareness programs to address digital technologies' benefits, also for other countries characterised by similar settings.

This paper can be seen in light of some limitations. The 221 valid answers are unbalanced demographically, the respondents being mostly women in the younger generations. Moreover, the modest number of entrepreneurs in the sample decreased the confidence in certain analyses pertaining to them.

Further research could focus on specific categories of digital entrepreneurship drivers and their relationships with the demographic variables or take a qualitative approach covering digital SMEs, especially in the light of the COVID-19 pandemic's influence over them. Future cross-country comparisons based on this analysis would also be interesting in order to enlarge the observations and generalise the evidence obtained.

Author Contributions: Conceptualization, S.A., O.B., I.B. and M.S.; methodology, S.A., O.B., I.B. and M.S.; validation, S.A., O.B., I.B. and M.S.; formal analysis, S.A., O.B., I.B. and M.S.; investigation, S.A., O.B., I.B. and M.S.; resources, S.A. and O.B.; data curation, S.A., O.B., I.B. and M.S.; writingoriginal draft preparation, S.A., O.B., I.B. and M.S.; writing-review and editing, S.A., I.B. and M.S.; supervision, S.A.; project administration, S.A. and M.S. All authors have read and agreed to the published version of the manuscript.

Funding: This research received no external funding.

Institutional Review Board Statement: Not applicable.

Informed Consent Statement: Not applicable.

Data Availability Statement: Not applicable.

Conflicts of Interest: The authors declare no conflict of interest.

\section{References}

Allen, Jonathan P. 2019. What Is Digital Entrepreneurship? Learning Digital Entrepreneurship. Available online: https://www. learndigitalentrepreneurship.com/2019/02/16/what-is-digital-entrepreneurship/ (accessed on 16 May 2021).

Amore, Mario, Valerio Pelucco, and Fabio Quarato. 2020. Family Ownership during the COVID-19 Pandemic. SSRN. Available online: https:/ / papers.ssrn.com/sol3/papers.cfm?abstract_id=3603991 (accessed on 21 May 2021).

Anagnoste, Sorin, Isabelle Biclesanu, Claude Chailan, and Bianca Negoiasa. 2020. Effective Web Presence Solutions for Enhancing e-Fashion Customers' Satisfaction. Present at the 3rd International Conference on Economics and Social Sciences, Bangkok, Thailand, August 16. [CrossRef]

Anagnoste, Sorin, Isabelle Biclesanu, Fabrizio D'Ascenzo, and Marco Savastano. 2021. The Role of Chatbots in End-To-End Intelligent Automation and Future Employment Dynamics. In Business Revolution in a Digital Era. Springer Proceedings in Business and Economics. Cham: Springer. [CrossRef]

Anderson, Somer. 2021. Guide to Economic Recession. Investopedia. Available online: https://www.investopedia.com/terms/r/ recession.asp (accessed on 16 May 2021).

Ang, Carmen, and Pernia Jamshed. 2021. Ranked: The Most Innovative Companies in 2021. Visual Capitalist. Available online: https:/ / www.visualcapitalist.com/ranked-the-most-innovative-companies-in-2021/ (accessed on 10 August 2021).

Antonizzi, Joshua, and Hanlie Smuts. 2020. The Characteristics of Digital Entrepreneurship and Digital Transformation: A Systematic Literature Review. Responsible Design, Implementation and Use of Information and Communication Technology 239: 12066. [CrossRef]

Ariguzo, Godwin, Efrem Mallach, and Steven White. 2006. The first decade of e-commerce. Journal of Business Information 1: 239-55. [CrossRef]

Balance. 2021. A Guide to B2B Payments in 2021; Get Balance. Available online: https:/ /www.getbalance.com/post/guide-to-b2bpayments-2021 (accessed on 29 May 2021).

BCG. 2021. Overcoming the Innovation Readiness Gap; Boston Consulting Group. Available online: https://web-assets.bcg.com/93/a7/7 d03fff34baa993929c81f220e72/bcg-most-innovative-companies-2021-apr-2021-r.pdf (accessed on 10 August 2021).

Bhatia, Saurabh. 2020. Mobile vs. Desktop (E-Commerce) and the Ultimate Marketing Strategy. Medium. Available online: https: // medium.com/roi-overload/the-ultimate-mobile-vs-desktop-marketing-strategy-692bbe59c324 (accessed on 16 May 2021).

BroadbandSearch. 2021. Mobile vs. Desktop Internet Usage (Latest 2021 Data). BroadbandSearch. Available online: https://www. broadbandsearch.net/blog/mobile-desktop-internet-usage-statistics (accessed on 29 May 2021).

Bruno. 2019. US B2B eCommerce Will Hit \$1.8 Trillion By 2023; Forrester. Available online: https://www.forrester.com/report/US+B2B+ eCommerce+Will+Hit+12+Trillion+By+2021/RES136173 (accessed on 10 August 2021).

Buchholz, Katharina. 2020. Almost Two Thirds of Ad Spending Is Digital; Statista. Available online: https://www.statista.com/chart/22 286/ad-spend-us-digital-traditional-split/ (accessed on 10 August 2021). 
Cassidy, Tabitha. 2019. Consumers Order More on Desktop than Mobile from Online Retailers. Digital Commerce 360. Available online: https: //www.digitalcommerce360.com/2019/07/24/consumers-order-more-on-desktop-than-mobile-for-online-retailers/ (accessed on 16 May 2021).

CSP. 2016. From Storefronts to Search Engines: A History of E-commerce; CSP. Available online: https:/ /online.csp.edu/blog/business / history-of-ecommerce/ (accessed on 29 May 2021).

Dapp, Thomas, Antje Stobbe, and Patricia Wruuck. 2012. The Future of (Mobile) Payments—New (Online) Players Competing with Banks. Frankfurt: Deutsche Bank, pp. 1-31.

Edosomwan, Simeon, Sitalaskshi Prakasan, Doriane Kouame, Jonelle Watson, and Tom Seymour. 2011. The history of social media and its impact on business. Journal of Applied Management and Entrepreneurship 16: 79-91.

Elia, Gianluca, Alessandro Margherita, Enrico Ciavolino, and Karim Moustaghfir. 2021. Digital Society Incubator: Combining Exponential Technology and Human Potential to Build Resilient Entrepreneurial Ecosystems. Administrative Sciences 11: 96. [CrossRef]

European Commission. 2020. Digital Economy and Society Index/Romania. European Commission: Available online: https: / ec.europa. eu/newsroom/dae/document.cfm?doc_id=66928 (accessed on 10 August 2021).

Fortune. 2021. Amazon-Fortune 500; Fortune. Available online: https://fortune.com/company/amazon-com/fortune500/ (accessed on 10 August 2021).

Gelter, Martin, and Julia Puaschunder. 2021. COVID-19 and Comparative Corporate Governance. ECGI Working Paper Series in Law. Available online: http:/ / ssrn.com/abstract_id=3772965 (accessed on 10 August 2021).

Johnson, Zac. 2021. How Much Does It Cost to Start an Online Business? Business. Available online: https: / www.business.com/articles / costs-of-starting-online-business / (accessed on 16 May 2021).

Koetsier, John. 2021. Robots 10x Faster, 10x Cheaper: Modular Development Platform and 3D Printing Lets You Build Autonomous Robots Like Lego; Forbes. Available online: https:/ /www.forbes.com/sites/johnkoetsier/2021/07/20/robots-10x-faster-10x-cheapermodular-development-platform-and-3d-printing-lets-you-build-autonomous-robots-like-lego/?sh=48b9b4cc3b5d (accessed on 15 October 2021).

Lai, Poey Chin. 2017. The literature review of technology adoption models and theories for the novelty technology. JISTEM 1: 21-38. [CrossRef]

Lai, Poey Chin, and Arffin Ahmad Zainal. 2015. Perceived Risk as an Extension to TAM Model: Consumers' Intention To Use A Single Platform E-Payment. Australia Journal Basic and Applied Science 9: 323-30.

Le Dinh, Thang, Manh Vu, and Ayi Ayayi. 2018. Towards a living lab for promoting the digital entrepreneurship process. International Journal of Entrepreneurship 22: 1-17.

McCullough, Brian. 2018. A Revealing Look at the Dot-Com Bubble of 2000-And How It Shapes Our Lives Today; TED. Available online: https://ideas.ted.com/an-eye-opening-look-at-the-dot-com-bubble-of-2000-and-how-it-shapes-our-lives-today/ (accessed on 29 May 2021).

Miva. 2011. The History of Ecommerce: How Did It All Begin? Miva. Available online: https://www.miva.com/blog/the-history-ofecommerce-how-did-it-all-begin/ (accessed on 29 May 2021).

OECD. 1997. National Innovation Systems; OECD. Available online: https://www.oecd.org/science/inno/2101733.pdf (accessed on 15 October 2021).

Patel, Divyesh, and Naresh Patel. 2020. COVID-19 and corporate governance (India): Practical issues, implications and new relief measures. SSRN. Available online: https:/ / papers.ssrn.com/sol3/papers.cfm?abstract_id=3690805 (accessed on 10 August 2021).

Rayna, Thierry, and Ludmila Striukova. 2021. Assessing the effect of 3D printing technologies on entrepreneurship: An exploratory study. Technological Forecasting and Social Change 164: 120483. [CrossRef]

Sahut, Jean-Michel, Luca Iandoli, and Frederic Teulon. 2021. The age of digital entrepreneurship. Small Business Economics 56: $1159-69$. [CrossRef]

Samara, Georges, and Jessica Terzian. 2020. Challenges and Opportunities for Digital Entrepreneurship in Developing Countries. In Digital Entrepreneurship Impact on Business and Society. Cham: Springer. [CrossRef]

Satalkina, Liliya, and Gerald Steiner. 2020a. Digital Entrepreneurship and its Role in Innovation Systems: A Systematic Literature Review as a Basis for Future Research Avenues for Sustainable Transitions. Sustainability 12: 2764. [CrossRef]

Satalkina, Liliya, and Gerald Steiner. 2020b. Digital Entrepreneurship: A Theory-Based Systematization of Core Performance Indicators. Sustainability 12: 4018. [CrossRef]

Savastano, Marco, and Sorin Anagnoste. 2020. Pioneering Strategies in Retail Settings: An Empirical Study of Successful Practices. Management \& Marketing 15: 643-63.

Schallmo, Daniel, and Christopher Williams. 2018. History of Digital Transformation. In Digital Transformation Now! Cham: Springer. [CrossRef]

Sharwood, Simon. 2014. Netscape Navigator-The Browser that Started It All-Turns 20; The Register. Available online: https:/ /www. theregister.com/2014/10/14/netscape_navigator_the_browser_that_started_it_all_turns_20/(accessed on 10 August 2021).

Smith, Kalen. 2011. History of the Dot-Com Bubble Burst and How to Avoid Another; Money Crashers. Available online: https: //www.moneycrashers.com/dot-com-bubble-burst/ (accessed on 10 August 2021).

Statista. 2021a. Average Selling Price of Desktop Personal Computers (PCs) Worldwide from 2005 to 2015; Statista. Available online: https:/ / www.statista.com/statistics/203759/average-selling-price-of-desktop-pcs-worldwide/ (accessed on 29 May 2021). 
Statista. 2021b. Distribution of Digital Advertising Spending in the United Kingdom (UK) from 201 to 2025, by Device; Statista. Available online: https://www.statista.com/statistics/456263/digital-market-outlook-uk-digital-advertising-revenue-by-device/ (accessed on 10 August 2021).

Statista. 2021c. Retail e-Commerce Sales Worldwide from 2014 to 2024; Statista. Available online: https:/ /www.statista.com/statistics/3790 46/worldwide-retail-e-commerce-sales/ (accessed on 10 August 2021).

Sussan, Fiona, and Zoltan Acs. 2017. The digital entrepreneurial ecosystem. Small Business Economics 49: 55-73. [CrossRef]

Tai, Jack. 2021. Startup Surge: Pandemic Causes New Businesses to Double; Forbes. Available online: https://www.forbes.com/sites/ theyec/2021/01/20/startup-surge-pandemic-causes-new-businesses-to-double/ (accessed on 15 May 2021).

Teneva, Dimira. 2021. The Customer Journey: The One Thing That Fixes Everything in E-Commerce; Metrilo. Available online: https: //www.metrilo.com/blog/customer-journey-ecommerce (accessed on 10 August 2021).

Tiron-Tudor, Adriana, and Delia Deliu. 2021. Big Data's Disruptive Effect on Job Profiles: Management Accountants' Case Study. Journal of Risk and Financial Management 14: 376. [CrossRef]

Tiron-Tudor, Adriana, Delia Deliu, Nicoleta Farcane, and Adelina Dontu. 2021. Managing change with and through blockchain in accountancy organizations: A systematic literature review. Journal of Organizational Change Management 34: 477-506. [CrossRef]

UNCTAD. 2021. Global E-Commerce Jumps to \$26.7 Trillion, COVID-19 Boosts Online Sales. UNCTAD. Available online: https: / / unctad.org/news/global-e-commerce-jumps-267-trillion-covid-19-boosts-online-sales (accessed on 29 May 2021).

Venkatesh, Viswanath, and Fred Davis. 1996. A model of the antecedents of perceived ease of use: Development and test. Decision Sciences 27: 451-81. [CrossRef]

Venkatesh, Viswanath, Michael Morris, Gordon Davis, and Fred Davis. 2003. User Acceptance of Information Technology: Toward a Unified View. MIS Quarterly 27: 425-78. [CrossRef] 